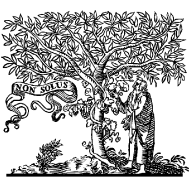

ELSEVIER MASSON
Elsevier Masson France

EM|consulte

www.em-consulte.com
Available online at

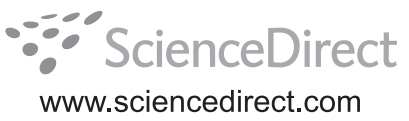

www.sciencedirect.com

Review

\title{
The genetic background of ankylosing spondylitis
}

\author{
Anikó Végvári ${ }^{\mathrm{a}}$, Zoltán Szabó ${ }^{\mathrm{a}}$, Sándor Szántó ${ }^{\mathrm{a}}$, Tibor T. Glant ${ }^{\mathrm{b}}$, \\ Katalin Mikecz ${ }^{\mathrm{b}}$, Zoltán Szekanecz ${ }^{\mathrm{a}, *}$ \\ ${ }^{a}$ Department of Rheumatology, Institute of Medicine, University of Debrecen Medical and Health Science Center, \\ 22, Móricz street, Debrecen, H-4032, Hungary \\ b Section of Molecular Medicine, Department of Orthopedic Surgery, Biochemistry and Internal Medicine (Section of Rheumatology), \\ Rush University Medical Center, Chicago, Illinois, USA
}

Accepted 24 February 2009

\begin{abstract}
It has long been known that the major histocompatibility complex (MHC) is essentially involved in genetic susceptibility to ankylosing spondylitis (AS). The HLA-B27 antigen has been accounted for 20 to $50 \%$ of the total genetic risk for this disease. However, susceptibility to AS cannot be fully explained by associations with the MHC. Recent studies including linkage analyses as well as candidate gene and, most recently, genome-wide association studies indicate significant associations of the interleukin-1 gene cluster, interleukin-23 receptor and ARTS1 genes as well as other possible loci with AS. In the murine model of proteoglycan-induced spondylitis, two susceptibility loci termed Pgis 1 and Pgis 2 were identified. Thus, AS is not a single-gene disease and the involvement of multiple non-MHC genes may account for the individual as well as geographical differences seen in AS.
\end{abstract}

(C) 2009 Published by Elsevier Masson SAS on behalf of the Société Française de Rhumatologie.

Keywords: Ankylosing spondylitis; Genetics; HLA-B27; Non-MHC genes; Linkage studies; Genome-wide association studies

\section{Introduction}

Ankylosing spondylitis (AS) is the prototype of spondyloarthropathies $(\mathrm{SpA})$, a group of inflammatory rheumatic diseases with shared genetic background as well as common clinical features [1]. Family clustering is an important feature of AS that suggests the role of genetic factors in susceptibility to AS $[2,3]$. For example, in families of SpA patients, additional SpA cases occur mostly among HLA-B2 $7^{+}$relatives $[4,5]$. Regarding twin studies in AS, in a Finnish study, the concordance was $50 \%$ between monozygotic twins, $15 \%$ overall among dizygotic twins and 20\% among HLA-B2 $7^{+}$dizygotic twins [6]. Differences in concordance rates between monozygotic and dizygotic twins indicate the crucial role of genetic factors in susceptibility to AS [6].

Considering the role of genes, the major histocompatibility complex (MHC) alone is not sufficient to explain the heritabil-

\footnotetext{
* Corresponding author.

E-mail addresses: szekanecz@iiibel.dote.hu,szekanecz@hotmail.com (Z. Szekanecz).
}

ity of AS. While more than $90 \%$ of Caucasian AS patients are HLA-B $27^{+}$, only less than $5 \%$ of HLA-B $27^{+}$members of the general population develop AS [7-9]. Thus, HLA-B27 has been accounted for only approximately 20 to $50 \%$ of the overall genetic susceptibility to AS $[10,11]$.

Although the etiology of the disease is unknown, environmental and genetic components have been implicated as predisposing factors. The dominant genetic component is the class I MHC encoded human leukocyte antigen HLA-B27, but the presence of HLA-B27 alone is insufficient for disease development $[2-4,11,12]$. There are two major hypotheses which explain the association of HLA-B27 with AS. The receptor theory assumes that certain $\mathrm{T}$ cell receptors can recognize a complex of foreign and $\mathrm{MHC}$ self peptides when together, but this putative pathogenic peptide is unknown [2-4]. The molecular mimicry hypothesizes that microorganisms which partially resemble or cross-react with HLA molecules are the source of antigenic components. This hypothesis of molecular mimicry targeted mostly Klebsiella and Yersinia antigens, but no appropriate microorganisms have yet been identified in patients with AS [11,13]. Therefore, extensive studies have been undertaken to identify other non-MHC genetic factors and, indeed, approximately a

1297-319X/\$ - see front matter @ 2009 Published by Elsevier Masson SAS on behalf of the Société Française de Rhumatologie. doi: $10.1016 / j$ jbspin.2009.02.006

Please cite this article in press as: Végvári A, et al. The genetic background of ankylosing spondylitis. Joint Bone Spine (2009), doi:10.1016/j.jbspin.2009.02.006 
59 dozen chromosome regions or gene clusters have been linked to AS [2-4].

Linkage analysis, genome-wide screening and candidate gene association studies have led to the identification of several non-MHC chromosome regions possibly linked to AS [2,3]. Some of these loci, such as the interleukin-1 (IL-1) gene cluster has been consistently reported by independent research groups $[2,14]$. Others, such as the genes of Aminopeptidase Regulator of TNF receptor Shedding 1 (ARTS1) (also known as Endoplasmic Reticulum-associated Aminopeptidase 1 [ERAP1]) and IL-23 receptor (IL-23R) have been described by the Wellcome Trust Case-Control Consortium (WTCCC) study group that had formerly performed the genome-wide association study of 14,000 cases of seven common diseases $[15,16]$. Yet, less information is available regarding the genetics of AS in comparison to, for example, rheumatoid arthritis (RA).

Despite of the increasing amount of data about genetic contributors, AS is a multifactorial disease, where the "conspiracy" of genes and environmental factors lead to the development of the well-known clinical symptoms. In this review, we summarize data on the genetic basis of AS based on both human and rodents studies. We will review the most relevant information on HLA as well as non-MHC alleles.

\section{Role of HLA-B27 and other major histocompatibility complex genes}

The association between HLA-B27 and AS was first reported in the early 1970s $[17,18]$. The prevalence of HLA-B27 is about 6 to $8 \%$ in the general population and more than $90 \%$ among AS patients $[3,7]$. As estimated by linkage analysis as well as HLAB27-dependent multiplicative model, the genetic contribution of HLA-B27 is about 20 to $35 \%$ [10,11,19-21]. The concordance rates for $\mathrm{HLA}-\mathrm{B} 27^{+}$mono- and dizygotic twins are 63 and $23 \%$, respectively [6].

Although there is no doubt that HLA-B27 is the major susceptibility gene for AS, its mechanism of action is still not known. All manifestations of SpA spontaneously develop in HLA-B27 transgenic rats indicating a direct role of this gene in disease susceptibility [22]. Among the 25 known HLA-B27 alleles, HLA-B*2705, the predominant allele in the Caucasian population, may be the original allele and all other alleles may be derived from HLA-B*2705 by mutation. Most allelic mutations affect the variable region and thus result in altered interactions between $T$ cell receptors and antigenic peptides [23]. While most other HLA-B27 alleles have been associated with SpA, HLAB*2706 and HLA-B*2709 occurring in South-East Asia and Sardinia, respectively, show no association with SpA [23].

In HLA-B alleles that confer susceptibility to $\mathrm{SpA}$, a presence of glutamic acid at position 45 and that of cysteine at position 67 of the HLA-B molecule is the specific pattern present in all alleles associated with SpA but absent in SpA-independent alleles. Based on these structural alterations, functional theories have emerged. The arthritogenic peptide theory suggests that this molecular structure enables the presentation of specific peptides that induce an autoimmune response. Regarding the impaired folding theory, disulfide bridges are formed between two cys- teines at position 67 resulting in altered intracellular trafficking of the molecules [24,25].

MHC genes other than HLA-B may also be involved in the development of SpA. These genes may include class II MHC alleles (HLA-DR genes), tumor necrosis factor- $\alpha$ (TNF- $\alpha$ ) and complement genes as well as some genes involved in antigen presentation by class I MHC molecules including TAP, LMP2 and LMP7 [2-4]. Unfortunately, the predominant role of HLAB27 highly influences the interpretation of these results as the reported associations may rather be attributable to linkage disequilibrium between the mentioned loci and HLA-B27. Only the direct additional effect of HLA-DR4 has been confirmed in HLA-B27 ${ }^{+}$relatives of SpA patients [24].

\section{Non-major histocompatibility complex alleles in ankylosing spondylitis}

As discussed above, MHC accounts for less than $50 \%$ of the genetic risk for AS. Various techniques have been used to study the contribution of non-MHC genes to susceptibility to and severity of human AS [2-4] (Table 1).

Animal models are invaluable aids for the research of human (autoimmune) disorders. The ank/ank mouse has a loss-offunction mutation in the ank gene and develops a progressive SpA, similar to human AS [19,26], but the ank gene, either in humans or mice, is not involved in autoimmune processes [26,27]. Other models of SpA have been developed in HLAB27 transgenic rodents [21], or in transgenic mice expressing a mutant type IX collagen or a truncated form of TNF- $\alpha$ [28]. In addition to human data, proteoglycan (PG)-induced spondylitis (PGIS), an autoimmune murine model of SpA will also be briefly discussed [29,30].

\section{Linkage studies}

Linkage exists when a candidate gene and another known locus are very close to each other, therefore, the two loci are transmitted together. Such linkage studies can be carried out in large families with many family members affected by a given disease. In these studies, results are presented as a non-parametric linkage score (NPL), which is then converted to a log odds ratio (LOD) score. High LOD values (LOD $\geq 3.6$ ) indicate significant associations, while LOD greater or equal to 2.2 values are suggestive [31].

There have been four large linkage studies with respect to susceptibility to AS. In the North-American Spondylitis Consortium (NASC) study, 185 families with 255 affected sibling pairs were analyzed. The most significant associations were attributed to the MHC locus located on chromosome $6(\mathrm{LOD}=15.6)$ and a single non-MHC locus on chromosome 16 (LOD = 4.7). Other loci with suggestive LOD values were located on chromosomes 1, 3, 4, 5, 10, 11, 17 and 19 [19]. In the French AS genetics cohort (GFEGS), 180 families with 244 affected sibling pairs were assessed. Again, the MHC locus had the strongest linkage [21]. Also in this cohort, a region on the short arm of chromosome 9 was significantly associated with acute anterior uveitis but not with AS [21]. Two studies from Oxford studies confirmed 
Table 1

Associations of non-major histocompatibility genes with ankylosing spondylitis.

\begin{tabular}{|c|c|c|}
\hline Type of study & Genetic linkage & Reference(s) \\
\hline \multirow[t]{2}{*}{ Genome-wide association studies (WTCCC) } & Interleukin-23 receptor (IL-23R; chromosome 1$)^{\mathrm{a}}$ & {$[15,16]$} \\
\hline & ARTS1 (chromosome 5) ${ }^{\mathrm{a}}$ & {$[15,16]$} \\
\hline Candidate gene association studies & Interleukin-1 gene cluster $(I L-1 A, I L-1 B, I L-1 R N)(\text { chromosome } 2)^{\mathrm{a}}$ & {$[14,35,36,38-41]$} \\
\hline \multirow[t]{10}{*}{ Linkage studies } & Chromosome 1 & [26] \\
\hline & Chromosome 3 & {$[20]$} \\
\hline & Chromosome 4 & {$[19]$} \\
\hline & Chromosome 9 & {$[20,26]$} \\
\hline & Chromosome $10^{\mathrm{a}}$ & {$[19,20,26]$} \\
\hline & Chromosome 11 & {$[19]$} \\
\hline & Chromosome 13 & [21] \\
\hline & Chromosome $16^{\mathrm{a}}$ & {$[19-21,26]$} \\
\hline & Chromosome 17 & {$[19,21]$} \\
\hline & Chromosome 19 & {$[19,20,26]$} \\
\hline
\end{tabular}

WTCCC: Wellcome Trust Case-Control Consortium

a Confirmed strong association.

the strongest linkage with the MHC region and suggested linkage with loci on chromosomes 2, 3, 9, 10, 11, 16 and 19 [26] (Table 1).

A pooled meta-analysis indicated the most clear evidence for linkage to $\mathrm{MHC}$ on chromosome 6. Additional strong linkage was observed with regions on chromosomes 16 and 10, while moderate linkage was seen with loci on chromosomes $2,3,4,5$, 6,11 and 17 [14].

Some loci were also associated with disease activity and functional severity. While MHC showed no linkage, regions on chromosome 18 were significantly associated with the BASDAI score. In addition, regions on the long arm of chromosome 2 exerted suggestive linkage with the BASFI functional impairment score [27].

\section{Candidate gene associations}

There have been conflicting results regarding the IL-1 gene cluster. This gene complex is located on chromosome 2 and includes genes encoding IL-1 $\alpha$ (IL-1A), IL-1 $\beta$ (IL-1B), IL-1 receptor antagonist $(I L-1 R N)$ and other genes (ILIF5.ILIF10) [32]. This gene cluster corresponds to the region on chromosome 2 identified in linkage studies described above $[14,26]$. IL-1 $\alpha$ and IL-1 $\beta$ are pro-inflammatory cytokines primarily produced by monocyte/macrophages, which stimulate the release of other inflammatory mediators including prostaglandins, matrix metalloproteinases and other cytokines as well as the expression of various adhesion receptors [33,34]. IL-1Ra competitively block the binding of IL- $1 \alpha$ and IL- $1 \beta$ to their receptor and thus antagonize the effects of these cytokines [34]. While early small studies suggested association between AS and the $I L-I R N$ gene encoding IL-1Ra [35,36], further larger studies could not confirm this association [37-39]. However, some small studies and a recent meta-analysis showed higher carriage of a variable nucleotide tandem repeat (VNTR) in intron 2 of the $I L-1 R N$ gene in AS patients compared to controls $[35,36,40]$. Moreover, two SNP in exon 6 of the $I L-I R N$ gene were also associated with AS [40]. Regarding other genes in the IL-1 cluster, altogether 14 SNP in the $I L-I A$ and $I L-1 B$ genes exerted significant associations with AS $[39,41]$. Among these SNP, SNP rs3783526 in the $I L-1 A$ and rs1 143627 in the $I L-1 B$ gene showed the most significant associations [39]. In addition, SNP rs2856836, rs17561 and rs 1894399 in the $I L-1 A$ gene also showed very strong associations [41] (Table 1).

\section{Genome-wide association studies}

As described above, the WTCCC initiative identified two new loci strongly associated with AS, IL-23R and ARTS1 $[15,16]$ (Table 1). IL-23R has been implicated in the pathogenesis of RA, psoriasis and inflammatory bowel diseases (IBD) [42-44]. IL-23 is a potent pro-inflammatory cytokine that stimulates the generation of Th17 cells as well as the production of other cytokines including TNF- $\alpha$, IL-6, IL-17 and IL-22. The gene for the IL-23R protein is located on chromosome 1 . Susceptibility to Crohn's disease and psoriasis has been associated with the SNP rs11209026 [42,43]. In addition, SNP rs7530511 is also associated with psoriasis [43]. Apart from the SNP mentioned above, several other SNP including rs10889677 and rs2201841 also had significantly increased prevalence in Crohn's disease in comparison to controls [42]. We have recently confirmed that SNP rs10889677 and rs2201841 are not only associated with IBD, but also with RA [44]. In the WTCCC cohort, eight IL-23R SNP were genotyped in 1000 AS patients and 1500 controls. Seven out of these eight SNP showed association with AS. Highly significant associations were found with SNP rs11209032, rs11209026 and rs10489629 [16,45]. Associations between IL-23R gene polymorphisms and AS have recently been confirmed in a Spanish cohort [46]. The IL-23R gene is responsible for $9 \%$ of the population-attributable risk of AS $[15,16]$.

As far as ARTS1 is concerned, this protein is an aminopeptidase in the endoplasmic reticulum. ARTS1, also known as ERAP1, cleaves receptors for cytokines including TNF- $\alpha$ (TNFR1), IL-1 (IL-1R2) and IL-6 (IL-6R $\alpha$ ) from the cell surface [47]. ARTS1 is also involved in the processing of antigenic 
peptides to optimal length for antigen presentation [48]. The three genes encoding ARTS1 are located on chromosome 5 [49]. In the WTCCC cohort and follow-up studies, five SNP including rs27044, rs30187, rs17482078, rs10050860 and rs2287987 were associated with AS [16]. In addition, there is no association between any ARTS1 SNP and either Crohn's disease or ulcerative colitis [16]. Thus, ARTS1 may not be involved in the pathogenesis of various SpA but its effects may be specific for AS within the SpA family. The ARTS1 gene is responsible for $26 \%$ of the overall risk of AS $[15,16]$.

\section{Other genes with unconfirmed associations}

As discussed above, the associations of IL-1 cluster genes, IL-23R and ARTS1 genes have been confirmed in large cohorts. There have been small studies suggesting the associations of other genes with AS.

Some alleles of the cytochrome P450 CYP2D6 gene located on chromosome 22 have been weakly associated with AS [50]. There have been controversies regarding possible associations of AS with the transforming growth factor- $\beta$ (TGF- $\beta$ ), ANKH and Toll-like receptor 4 (TLR4) genes. While some studies suggested marginal associations of these genes with AS [51-53], other studies could not confirm this [54-56]. Finally, NOD2/CARD15 mutations have been associated with Crohn's disease, however, several studies confirmed that there were no such associations with AS [57].

\section{Lessons from the proteoglycan-induced spondylitis model}

Polyarthritis and spondylitis can be induced in susceptible mouse strains by immunization with human cartilage PG $[58,59]$. PGIS shows similarities to AS in terms of clinical and radiological features. PGIS was induced in susceptible BALB/c and $\mathrm{C} 3 \mathrm{H} / \mathrm{HeJCr}(\mathrm{C} 3 \mathrm{H})$ strains of mice, and in their $\mathrm{F} 1$ and F2 generations derived from intercrosses with arthritis- and/or spondylitis-resistant DBA/2 and DBA/1 parent strains, by systemic immunization with cartilage PG. Almost all (97-100\%) PG-immunized BALB/c and $\mathrm{C} 3 \mathrm{H}$ mice developed peripheral arthritis by 2 weeks after the third antigen injection. Massive inflammatory cell infiltration, pannus formation, and cartilage and bone erosion characterized the histopathologic picture of the affected joints. None of the DBA/ 1 or DBA/2 parents nor the $(\mathrm{BALB} / \mathrm{c} \times \mathrm{DBA} / 2) \mathrm{F} 1$ hybrids developed arthritis until the end of the 14-18-week experimental period. The incidence and severity of spondylitis were highly comparable in both PGISsusceptible inbred strains (BALB/c and C3H) [29].

Although $\mathrm{F} 1$ hybrids of the $\mathrm{BALB} / \mathrm{c} \times \mathrm{DBA} / 2$ intercross were fully resistant to peripheral PGIA, unexpectedly, more than $30 \%$ of them developed PGIS, whereas none of the F1 hybrids of BALB/c $\times$ DBA/1 developed PGIS [23]. These observations suggest that the DBA/1 strain carries very strong protective genes against $\mathrm{SpA}$, while the DBA/2 genome may contain both spondylitis susceptibility and protective genes that might be silent in the original background.
Quantitative trait analysis was used in order to identify and characterize non-MHC chromosome loci that may be highly associated with the development of PGIS [30]. Two major loci exerted highly significant linkage, accounting for $40 \%$ of the trait variance in the $\mathrm{BALB} / \mathrm{c} \times \mathrm{DBA} / 2 \mathrm{~F} 2$ generation. The dominant spondylitis-susceptibility allele for the Pgis2 locus (mouse chromosome 2) was derived from the BALB/c strain, whereas the Pgisl (chromosome 18) recessive allele was present in the arthritis-resistant DBA/2 strain. The Pgis I locus significantly affected the disease-controlling Pgis2 locus, inducing as high incidence of spondylitis in F2 hybrids as was found in the spondylitis-susceptible parent BALB/c strain. Additional disease-controlling loci with suggestive linkage were mapped to the chromosomes 12, 15, and 19. A major locus controlling IL-6 production was found on chromosome 14 close to the gene of osteoclast differentiation factor Tnfsf11. Locus on chromosome 11 near the Stat3 and Stat5 genes controlled serum levels of the immunoglobulin IgG2a isotype. The two major genetic loci Pgis1 and Pgis2 of murine spondylitis were homologous to chromosome regions in human genome, which control AS in human patients [30]. The first murine locus (Pgis1) is homologous to human chromosomes $5 q$ and $18 \mathrm{q}$, both of which have significant linkage with AS found in British and European kindreds [19,27,60]. The Pgia2 locus overlaps with the cluster of $I L-1$ and Arts genes implicated in susceptibility to AS in humans as described above $[2,15,16,38]$.

\section{Conclusions}

It is evident that the MHC, especially HLA-B27, plays a central role in susceptibility to AS. For example, HLA-B27 confers approximately 20 to $50 \%$ of the total genetic risk for this disease. However, AS is definitely not a single gene disease and the genetic background of AS cannot be fully explained by associations with the MHC. Candidate gene and, recently, genome-wide association studies have confirmed the strong association of IL1 cluster on chromosome 2, IL-23R gene on chromosome 1 and ARTS1 genes on chromosome 5 with AS. Linkage analysis confirmed possible associations with other regions. The strongest linkage was observed for loci on chromosome 16, while moderate linkage was suggested at sites on chromosomes 3, 10, 11, 17 and 19. In the PGIS animal model, two susceptibility loci termed Pgis 1 and Pgis2 were identified.

\section{References}

[1] van der Linden SM, van der Heijde D, Maksymowych WP. Ankylosing spondylitis. In: Firestein GS, Budd RC, Harris Jr ED, McInnes IB, Ruddy S, Sergent JS, editors. Kelley's textbook of rheumatology, II, 8th edition Philadelphia: Saunders-Elsevier; 2008. p. 1169-90 [Chapter 70].

[2] Brionez TF, Reveille JD. The contribution of genes outside the major histocompatibility complex to susceptibility to ankylosing spondylitis. Curr Opin Rheumatol 2008;20:384-91.

[3] Breban M, Miceli-Richard C, Zinovieva E, et al. The genetics of spondyloarthropathies. Joint Bone Spine 2006;73:355-62.

[4] Brown MA. Breakthroughs in genetic studies of ankylosing spondylitis. Rheumatology 2008;47:132-7. 
[5] Said-Nahal R, Miceli-Richard C, Berthelot JM, et al. The familial form of spondylarthropathy: a clinical study of 115 multiplex families. Arthritis Rheum 2000;43:1356-65.

[6] van der Linden SM, Valkenburg HA, de Jongh BM, et al. The risk of developing ankylosing spondylitis in HLA-B27 positive individuals. Arthritis Rheum 1984;27:361-8.

[7] Brown MA, Kennedy LG, MacGregor AJ, et al. Susceptibility to ankylosing spondylitis in twins: the role of genes, HLA, and the environment. Arthritis Rheum 1997;40:1823-8.

[8] Brown MA, Pile KD, Kennedy LG, et al. HLA class I associations of ankylosing spondylitis in the white population in the United Kingdom. Ann Rheum Dis 1996;55:268-70.

[9] Reveille JD. Major histocompatibility genes and ankylosing spondylitis. Best Pract Res Clin Rheumatol 2006;20:601-9.

[10] Gran JT, Husby G, Hordvik M, et al. Prevalence of ankylosing spondylitis in males and females in a young middle-aged population of Tromso, northern Norway. Ann Rheum Dis 1985;44:359-67.

[11] Braun J, Bollow M, Remlinger G, et al. Prevalence of spondylarthropathies in HLA-B27 positive and negative blood donors. Arthritis Rheum 1998;41:58-67.

[12] Khan MA. Update on spondyloarthropathies. Ann Intern Med 2002;136:896-907.

[13] Ebringer A, Wilson C. HLA molecules, bacteria and autoimmunity. J Med Microbiol 2000;49:305-11.

[14] Carter KW, Pluzhnikov A, Timms AE, et al. Combined analysis of three whole genome linkage scans for ankylosing spondylitis. Rheumatology 2007;48:763-71.

[15] The Wellcome Trust Case Control Consortium. Genome-wide association study of 14,000 cases of seven common diseases and 3,000 shared controls. Nature 2007;447:661-83.

[16] Wellcome Trust Case Control Consortium, The Australo-Anglo-American Spondylitis Consortium. A genome-wide scan of 14,000 non-synonymous coding SNP in 5,500 individuals. Nat Genet 2007;39:1329-36.

[17] Amor B, Feldmann JL, Delbarre F, et al. HLA antigen W27 - a genetic link between ankylosing spondylitis and Reiter's syndrome? N Engl J Med 1974;290:572.

[18] Brewerton DA, Hart FD, Nicholls A, et al. Ankylosing spondylitis and HLA-B27. Lancet 1973;1:904-7.

[19] Laval SH, Timms A, Edwards S, et al. Whole-genome screening in ankylosing spondylitis: evidence of non-MHC genetic-susceptibility loci. Am J Hum Genet 2001;68:918-26.

[20] Miceli-Richard C, Zouali H, Said-Nahal R, et al. Significant linkage to spondylarthropathy on 9q31-34. Hum Mol Genet 2004;13:1641-8.

[21] Zhang G, Luo J, Bruckel J, et al. Genetic studies in familial ankylosing spondylitis susceptibility. Arthritis Rheum 2004;50:2246-54.

[22] Breban M, Hacquard-Bouder C, Falgarone G. Animal models of HLAB27-associated diseases. Curr Mol Med 2004;4:21-40.

[23] Hildebrand WH, Turnquist HR, Prilliman KR, et al. HLA class I polymorphism has a dual impact on ligand binding and chaperone interaction. Hum Immunol 2002;63:248-55

[24] Colbert RA. The immunobiology of HLA-B27: variations on a theme. Curr Mol Med 2004;4:21-30.

[25] Kuon W, Kuhne M, Busch DH, et al. Identification of novel human aggrecan T cell epitopes in HLA-B27 transgenic mice associated with spondyloarthropathy. J Immunol 2004;173:4859-66.

[26] Brown MA, Pile KD, Kennedy GL, et al. A genome-wide screen for susceptibility loci in ankylosing spondylitis. Arthritis Rheum 1998;41 588-95.

[27] Brown MA, Brophy S, Bradbury L, et al. Identification of major loci controlling clinical manifestations of ankylosing spondylitis. Arthritis Rheum 2003;48:2234-9.

[28] Krug HE, Wietgrefe MM, Ytterberg ST, et al. Murine progressive ankylosis is not immunologically mediated. J Rheumatol 1997;24:115-22.

[29] Szabo Z, Szanto S, Vegvari A, et al. Genetic control of experimental spondylarthropathy. Arthritis Rheum 2005;52:2452-60.

[30] Vegvari A, Szabo Z, Szanto S, et al. Two major interacting chromosome loci control disease susceptibility in murine model of spondyloarthropathy. J Immunol 2005;175:2475-83
[31] Lander E, Kruglyak L. Genetic dissection of complex traits: guidelines for interpreting and reporting linkage results. Nat Genet 1995;11: 241-7.

[32] Brown MA. Nonmajor-histocompatibility-complex genetics of ankylosing spondylitis. Best Pract Res Clin Rheumatol 2006;20:611-21.

[33] Jacques C, Gosset M, Berenbaum F, et al. The role of IL1 and IL1-Ra in joint inflammation and cartilage degradation. Vitam Horm 2006;74: 371-403.

[34] Szekanecz Z, Koch AE. Cytokines. In: Ruddy S, Harris Jr ED, Sledge CB, Budd RC, Sergent JS, editors. Kelley's textbook of rheumatology. 6th Edition Philadelphia: W.B. Saunders; 2001. p. 275-90 [Chapter II.20].

[35] McGarry F, Neilly J, Anderson N, et al. A polymorphism within the interleukin-1 receptor antagonist (IL-1Ra) gene is associated with ankylosing spondylitis. Rheumatology 2001;40:1359-64.

[36] van der Paardt M, Crusius JB, Garcia-Gonzalez MA, et al. Interleukin-1 $\beta$ and interleukin-1 receptor antagonist gene polymorphisms in ankylosing spondylitis. Rheumatology 2002;41:1419-23.

[37] Li J, Ge Z, Akey JM, et al. Lack of linkage of IL1RN genotypes with ankylosing spondylitis susceptibility. Arthritis Rheum 2004;50: 3047-8.

[38] Timms AE, Crane AM, Sims AM, et al. The interleukin-1 gene cluster contains a major susceptibility locus for ankylosing spondylitis. Am J Hum Genet 2004:75:587-95.

[39] Maksymowych WP, Rahman P, Reeve JP, et al. Association of the IL1 gene cluster with susceptibility to ankylosing spondylitis: an analysis of three Canadian populations. Arthritis Rheum 2006;54:974-85.

[40] Wu Z, Gu JR. A meta-analysis on interleukin-1 gene cluster polymorphism and genetic susceptibility for ankylosing spondylitis. Zhonghua Yi Xue Za Zhi 2007;87:433-7.

[41] Sims AM, Timms AE, Bruges-Armas J, et al. Prospective meta-analysis of IL-1 gene complex polymorphisms confirms associations with ankylosing spondylitis. Ann Rheum Dis 2008;67:1305-9.

[42] Duerr RH, Taylor KD, Brant SR, et al. A genome-wide association study identifies IL23R as an inflammatory bowel disease gene. Science 2006;314:1461-3

[43] Cargill M, Schrodi SJ, Chang M, et al. A large-scale genetic association study confirms IL12B and leads to the identification of IL23R as psoriasisrisk genes. Am J Hum Genet 2007;80:273-90.

[44] Faragó B, Magyari L, Safrany E, et al. Functional variants of interleukin23 receptor gene confer risk for rheumatoid arthritis but not for systemic sclerosis. Ann Rheum Dis 2008;67:248-50.

[45] Rahman P, Inman GD, Gladman DD, et al. Association of interleukin23 receptor variants with ankylosing spondylitis. Arthritis Rheum 2008;58:1020-5.

[46] Rueda B, Orozco G, Raya E, et al. The IL23R Arg381Gln non-synonymous polymorphism confers susceptibility to ankylosing spondylitis. Ann Rheum Dis 2008;67:1451-4.

[47] Cui X, Rouhani F, Hawari F, et al. An aminopeptidase, ARTS-1, is required for interleukin-6 receptor shedding. J Biol Chem 2003;278: $28677-85$.

[48] Hammer GE, Kanaseki T, Shastri N. The final touches make perfect the peptide-MHC class I repertoire. Immunity 2007;26:397-406

[49] Firat E, Saveanu L, Aichele P, et al. The role of endoplasmic reticulum-associated aminopeptidase 1 in immunity to infection and in cross-presentation. J Immunol 2007;178:2241-8

[50] Brown MA, Edwards S, Hoyle E, et al. Polymorphisms of the CYP2D6 gene increase susceptibility to ankylosing spondylitis. Hum Mol Genet 2000;9:1563-6

[51] Jaakkola E, Crane AM, Laiho K, et al. The effect of transforming growth factor $\beta 1$ gene polymorphisms in ankylosing spondylitis. Rheumatology 2004:43:32-8.

[52] Tsui HW, Inman RD, Paterson AD, et al. ANKH variants associated with ankylosing spondylitis. Arthritis Res Ther 2005;7:R513-25.

[53] Snelgrove T, Lim S, Greenwood C, et al. Association of toll-like receptor 4 variants and ankylosing spondylitis: a case-control study. J Rheumatol 2007:34:368-70.

[54] van der Paardt M, Crusius JB, Garcia-Gonzalez MA, et al. Susceptibility to ankylosing spondylitis: no evidence for the involvement of transform- 
ing growth factor beta 1 (TGFB1) gene polymorphisms. Ann Rheum Dis 2005;64:616-9.

[55] Timms AE, Zhang Y, Bradbury L, et al. Investigation on the role of ANKH in ankylosing spondylitis. Arthritis Rheum 2003;48:2898-902.

[56] Gergely P, Blazsek A, Weiszhar Z, et al. Lack of genetic association of the toll-like receptor 4 (TLR4) Asp299Gly and Thr399Ile polymorphisms with spondyloarthropathies in a Hungarian population. Rheumatology 2006;45:1194-6.

[57] van der Paardt M, Crusius JBA, de Koning MHMT, et al. CARD15 gene mutations are not associated with ankylosing spondylitis. Genes Immun 2003;4:77-8.
[58] Glant TT, Mikecz K, Arzoumanian A, et al. Proteoglycan-induced arthritis in BALB/c mice. Clinical features and histopathology. Arthritis Rheum 1987;30:201-12.

[59] Mikecz K, Glant TT, Poole AR. Immunity to cartilage proteoglycans in $\mathrm{BALB} / \mathrm{c}$ mice with progressive polyarthritis and ankylosing spondylitis induced by injection of human cartilage proteoglycan. Arthritis Rheum 1987;30:306-18.

[60] Pizcueta P, Luscinskas FW. Monoclonal antibody blockade of L-selectin inhibits mononuclear leukocyte recruitment to inflammatory sites in vivo. Am J Pathol 1994;145:461-9.

Please cite this article in press as: Végvári A, et al. The genetic background of ankylosing spondylitis. Joint Bone Spine (2009), doi:10.1016/j.jbspin.2009.02.006 